\title{
Electrostatic and Topological Features as Predictors of Antifungal Potential of Oxazolo Derivatives as Promising Compounds in Treatment of Infections Caused by Candida albicans
}

\author{
Strahinja Kovačević, ${ }^{1, \star}$ Milica Karadžić, ${ }^{1}$ Sanja Podunavac-Kuzmanović, ${ }^{1}$ \\ Lidija Jevrić, ${ }^{1}$ Evica Ivanović ${ }^{2}$ and Matilda Vojnovic ${ }^{3}$ \\ ${ }^{1}$ University of Novi Sad, Faculty of Technology Novi Sad, Bulevar cara Lazara 1, 21000 Novi Sad, Serbia \\ ${ }^{2}$ University of Belgrade, Faculty of Agriculture, Nemanjina 6, 11080 Belgrade-Zemun, Serbia \\ ${ }^{3}$ University of Novi Sad, Faculty of Medicine, Hajduk Veljkova 3, 21000 Novi Sad, Serbia \\ * Corresponding author: E-mail: strahko@uns.ac.rs, \\ phone: +381214853666 , fax: +38121450413
}

Received: $15-05-2017$

\begin{abstract}
The results presented in this study include the prediction of the antifungal activity of 24 oxazolo derivatives based on their topological and electrostatic molecular descriptors, derived from the 2D molecular structures. The artificial neural network (ANN) method was applied as a regression tool. The input data for ANN modeling were selected by stepwise selection (SS) procedure. The ANN modeling resulted in three networks with the outstanding statistical characteristics. High predictivity of the established networks was confirmed by comparisons of the predicted and experimental data and by the residuals analysis. The obtained results indicate the usefulness of the formed ANNs in precise prediction of minimum inhibitory concentrations of the analyzed compounds towards Candida albicans. The Sum of Ranking Differences (SRD) method was used in this study to reveal possible grouping of the compounds in the space of the variables used in ANN modeling. The obtained results can be considered to be a contribution to development of new antifungal drugs structurally based on oxazole core, particularly nowadays when there is a lack of highly efficient antimycotics.
\end{abstract}

Keywords: Artificial neural networks; Antifungal activity; Molecular topology; Electrostatic descriptors; QSAR; Sum of Ranking Differences

\section{Introduction}

Quantitative structure-activity relationship (QSAR) approach is an attempt to remove the trial-and-error element from drug design by using high-quality mathematical relationships which relate measurable physicochemical parameter(s) as independent variable(s) and a biological response (a dependent variable). ${ }^{1}$ These variables have been correlated in many QSAR studies applying various chemometric regression methods, as linear regression (LR), multiple linear regression (MLR), polynomial regression (PR), artificial neural networks (ANN), partial least squares regression (PLS), principal component regression (PCR), etc. ${ }^{2-8}$ Any high-quality model obtained by aforementioned chemometric techniques may be used by the chemist in order to facilitate the synthesis of more effective drugs. A high-quality QSAR model must be based on reasonable number of tested compounds, characterized by good values of statistical parameters, defined for particular application domain and suitably validated by internal and external validation approaches. Using these QSAR models, it is possible to precisely calculate the theoretical activity of compounds prior to their synthesis, and thus decrease financial expenses and time needed for the experimental work.

The selection of appropriate regression method depends on nature of the variables. ANN method is suitable for correlation analysis when there is a complex relation- 
ship between the variables, as in the case of biological systems. The complex relationships between biological activity and molecular characteristics are not unusual, since there are many factors which have certain influence on biological effect of a compound, such as lipophilicity, dissociation, molecular weight, presence of polar/non-polar functional groups, conformation, etc. In the present paper, the electrostatic and topological characteristics of benzoxazoles and oxazolo[4,5- $b]$ pyridines were used as predictors of their antifungal activity against Candida albicans. Topological descriptors of a compound can be calculated based on molecular graphs that are hydrogen-suppressed. In these graphs the bonds are presented by edges and atoms by vertices. ${ }^{9}$ Simple topological descriptors are based on the counting of some specific graph elements (Kier shape descriptors, Hosoya Z index, pat/walk shape indices, self-returning walk counts), but the most common topological descriptors are obtained by using some algebraic operators. ${ }^{9}$ In QSAR and quantitative structureproperty relationship (QSPR) modeling, the graph-invariants have been effectively used in characterization of the structural similarity and dissimilarity of compounds. ${ }^{9}$ There is no need for energy minimization of the molecular structure for calculation of topological descriptors. Electrostatic descriptors describe many of the electrical characteristics of molecules, such as polarity, dipole moment, polarizability, ionization energy, etc. These characteristics certainly have an influence on interactions between the molecule and its surroundings, in example interactions with cell membranes, extra- and intercellular molecules.

The most popular classes of molecules that are used in treatment of infections caused by Candida species are polyenes, azoles, analogs of nucleosides, allylamines, etc. In treatment of Candida albicans infections, fluconazole, as one of the members of azoles, is definitely one of the most popular antifungals. According to previous studies, Candida has developed high-level resistance toward some azole antifungal drugs. ${ }^{10}$ However, some oxazole analogs, such as oxazolo[4,5- $b$ ]pyridines and benzoxazoles expressed significant antifungal activity and are considered to be a very good basis for development of new antifungal therapeutics. This study presents our efforts to define sophisticated QSARs that would be limited on prediction of antifungal activity of structurally similar oxazolo[4,5-b] pyridines and benzoxazoles toward Candida albicans. The existing QSARs have been defined on the basis of MLR, PCR and PLS regression methods applying lipophilicity and some physicochemical descriptors. ${ }^{11-14}$ The ANN method with absorption, distribution, metabolism and excretion (ADME) descriptors was applied for the same purpose as well. ${ }^{14}$ However, this study explores the importance of topological and electrostatic characteristics of a series of benzoxazoles and oxazolo $[4,5-b]$ pyridines in prediction of their antifungal activity toward Candida albicans.

\section{Material and Methods}

\section{1. The Studied Series of Oxazolo[ $[4,5-b]$ pyridines and Benzoxazoles}

Structural formulae of the analyzed benzoxazoles and oxazolo $[4,5-b]$ pyridines are presented in Figure 1 . The

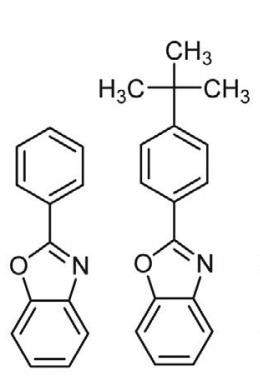

(1)

(2)<smiles>CNc1ccc(-c2nc3cc(Cl)ccc3o2)cc1</smiles>

(7)<smiles>Clc1ccc(-c2nc3cc(Cl)ccc3o2)cc1</smiles>

(8)<smiles>O=[N+]([O-])c1ccc(-c2nc3cc(Cl)ccc3o2)cc1</smiles>

(9)

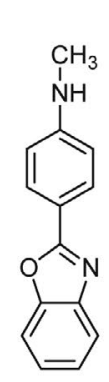

(4)

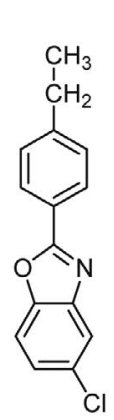

(5)<smiles>CC(=O)Nc1ccc(-c2nc3cc(Cl)ccc3o2)cc1</smiles>

(6)<smiles>CCc1ccc(-c2nc3cc(N)ccc3o2)cc1</smiles>

(10)<smiles>Nc1ccc(-c2nc3cc(F)ccc3o2)cc1</smiles>

(11)

(12)
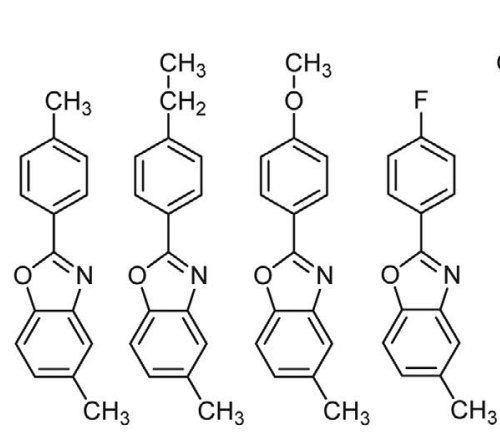<smiles>CNc1ccc(-c2nc3cc(C)ccc3o2)cc1</smiles>

(13)

(14)

(15)

(16)

(17)

(18)
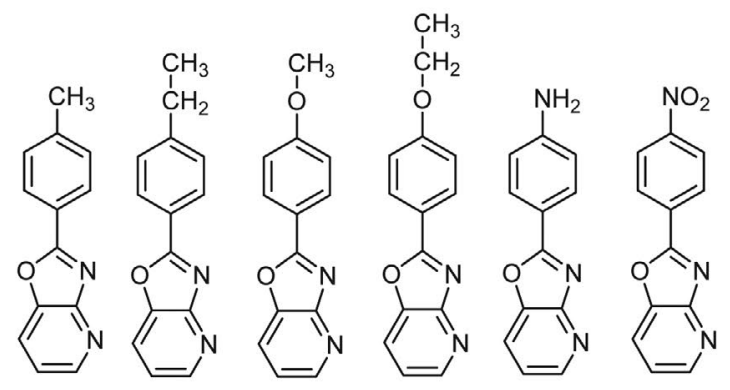

(19)

(20)

(21)

(22)

(23)

Figure 1. The molecular structures of the analyzed oxazole derivatives 
analyzed compounds possess various types of substituents/functional groups, including tert-butylphenyl, ethylphenyl, dimethyl, chlorophenyl, nitrophenyl, fluorophenyl, methoxyphenyl, ethoxyphenyl and acetamide groups. The experimental results of determination of the antifungal activity of studied derivatives against Candida albicans MTCC 183 are given in literature. ${ }^{15}$ Antifungal activity in the form of minimum inhibitory concentration (MIC), that was used in further QSAR-ANN modeling, was mathematically transformed in the form of logarithm of the MIC reciprocal value, $\log \left(1 / c_{\mathrm{MIC}}\right)$.

\section{2. Electrostatic and Topological Descriptors Calculation}

The set of 35 electrostatic and 10 topological descriptors was calculated by using PreADMET online software. ${ }^{16}$ The structural optimization and energy minimization were not required since the molecular descriptors were calculated on the basis of 2D structures. The values of the calculated descriptors are shown in Supplementary data (Table S1).

\section{3. Chemometric Methods}

The first step in chemometric analysis was the selection of the most appropriate descriptors which will be used as inputs in ANN modeling. For this purpose, stepwise selection (SS) procedure was applied by using NCSS statistical software. ${ }^{17}$ In the SS procedure minimum change in the root mean square error (RMSE) was used as a measure for removing or adding variables. In the present analysis, the limit of RMSE change was set at 0.05 .

Artificial neural networks are a non-linear chemometric tool. They have been widely applied in modeling of complex relationships between different type of variables, which is usually the case in prediction of biological activity of many biologically active compounds. An ANN consists of several layers: the input layer, one or more hidden layers, and one output layer. ${ }^{18}$ The ANNs were trained applying the feedforward multilayer perceptron (MLP) ANN function with Broyden-Fletcher-Goldfarb-Shanno (BFGS) learning algorithm in Statistica 10.0 software. ${ }^{19}$ The data normalization was carried out by min-max normalization method. ${ }^{20,21}$

Prior to ANN modeling, the analyzed compounds were divided into the training set (compounds $\mathbf{1}, \mathbf{2}, \mathbf{3}, \mathbf{4}, \mathbf{5}$, $6,8,9,11,13,15,17,18,19,20,21,22$ and 23 ), validation set (compounds 12,14 and 24) and test set (compounds 7 , 10 and 16).

The estimation of the contribution of every input variable in a network was done by calculation of Global sensitivity analysis (GSA) coefficients. ${ }^{22}$ A GSA coefficient describes the ANN's outputs changes that are caused by variations in the parameters that affect the ANN. If the GSA index is higher than 1, the greater change in ANN's performance is achieved with minor variation in the input variable. 22,23

The ANN models' validity was estimated on the basis of the following statistical parameters: $R$ (correlation coefficient), $R_{t r}$ (correlation coefficients of training set), $R_{t}$ (correlation coefficients of test set), $R_{v}$ (correlation coefficients of validation set), RMSE (root mean square error), $R M S E_{t r}$ (root mean square error of training set), $R M S E_{t}$ (root mean square error of test set), $R M S E_{v}$ (root mean square error of validation set), $F$-test, variation coefficient $(V C)$ and significance level $(p)$. Also, the analysis of residuals and the graphical comparison of predicted and experimental data were carried out in order to estimate predictive ability of ANN models.

SRD method was used as relatively new approach in comparison of samples, compounds, models. ${ }^{24}$ The purpose of the SRD analysis in this study was to reveal possible similarities or dissimilarities among the analyzed molecules on the basis of their topological and electrostatic descriptors used in ANN modeling. In the SRD analysis the row average values were used as the reference ranking. It is substantially different than hierarchical cluster analysis (HCA) and principal component analysis (PCA) approaches. The SRD methodology, its algorithms and practical uses are described in details in literature. ${ }^{24-26}$ The validation of SRD analysis was done by comparison of ranks by random numbers (CRRN) and 7-fold cross-validation. $^{24}$

\section{Results and Discussion 3. 1. The Selection of Suitable Variables - SS Procedure}

SS analysis was conducted after the descriptors calculation procedure. The significance level of 0.05 was required for a variable to enter the equation, while the significance level of 0.20 was used as a criterion for removal of variables from the model. The iterations number was set at

Table 1. The results of stepwise selection procedure.

\begin{tabular}{lcccc}
\hline $\begin{array}{l}\text { Iteration } \\
\text { number }\end{array}$ & Action & Variable & $\boldsymbol{R}^{\mathbf{2}}$ & Sqrt(MSE) \\
\hline 0 & Unchanged & & 0.0000 & 0.1253 \\
1 & Added & RPCS & 0.2914 & 0.1078 \\
2 & Added & PNSA1 & 0.5010 & 0.0926 \\
3 & Added & RNCS & 0.5764 & 0.0874 \\
4 & Added & FNSA1 & 0.6175 & 0.0853 \\
5 & Added & Rouvray_Index & 0.6963 & 0.0780 \\
6 & Added & FPSA1 & 0.8093 & 0.0636 \\
7 & Added & WI & 0.8990 & 0.0477 \\
8 & Added & Gutman_2D_MTI & 0.9150 & 0.0452 \\
9 & Added & TNC & 0.9240 & 0.0443 \\
10 & Unchanged & & 0.9240 & 0.0443 \\
\hline
\end{tabular}


500. As a result of SS analysis, the subset of 9 calculated descriptors was formed (Table 1).

The selected descriptors, suggested by SS analysis, are the following: RPCS (relative positive charge surface area), PNSA1 (partial negative surface area $1^{\text {st }}$ type), RNCS (relative negative charge surface area), FNSA1 (fractional charged partial negative surface area $1^{\text {st }}$ type), Rouvray index, FPSA1 (fractional charged partial positive surface area $1^{\text {st }}$ type), WI (Wiener index), Gutman 2D MTI (Gutman 2D molecular topological index) and TNC (total negative charge). This subset of 9 descriptors was used as the input variables for further ANN modeling.

\section{2. ANN Modeling and Validation of Models}

The ANN modeling resulted into three statistically very good models, whose activation functions and statisti-

Table 2. The results of ST-ANN procedure.

\begin{tabular}{lccc}
\hline $\begin{array}{l}\text { Network } \\
\text { architecture }\end{array}$ & MLP 9-7-1 & MLP 9-13-1 & MLP 9-14-1 \\
\hline $\boldsymbol{R}_{\text {train }}$ & 0.9701 & 0.9759 & 0.9726 \\
$\boldsymbol{R}_{\text {test }}$ & 0.9534 & 0.9909 & 0.9786 \\
$\boldsymbol{R}_{\text {val }}$ & 0.9986 & 0.9997 & 0.9986 \\
$\boldsymbol{R M S E}_{\text {train }}$ & 0.002930 & 0.002456 & 0.002875 \\
$\boldsymbol{R M S E}_{\text {test }}$ & 0.001077 & 0.000669 & 0.000082 \\
$\boldsymbol{R M S E}_{\text {val }}$ & 0.005169 & 0.013497 & 0.003369 \\
$\boldsymbol{F}$-test & 350.7 & 295.6 & 431.6 \\
$\boldsymbol{V} \boldsymbol{C}(\%)$ & 0.79 & 0.84 & 0.68 \\
$\boldsymbol{p}_{\text {-value }}$ & 0.000000 & 0.000000 & 0.000000 \\
Hidden activation & Tanh & Tanh & Tanh \\
Output activation & Exponential & Exponential & Exponential \\
Training algorithm & BFGS 20 & BFGS 20 & BFGS 19 \\
\hline
\end{tabular}

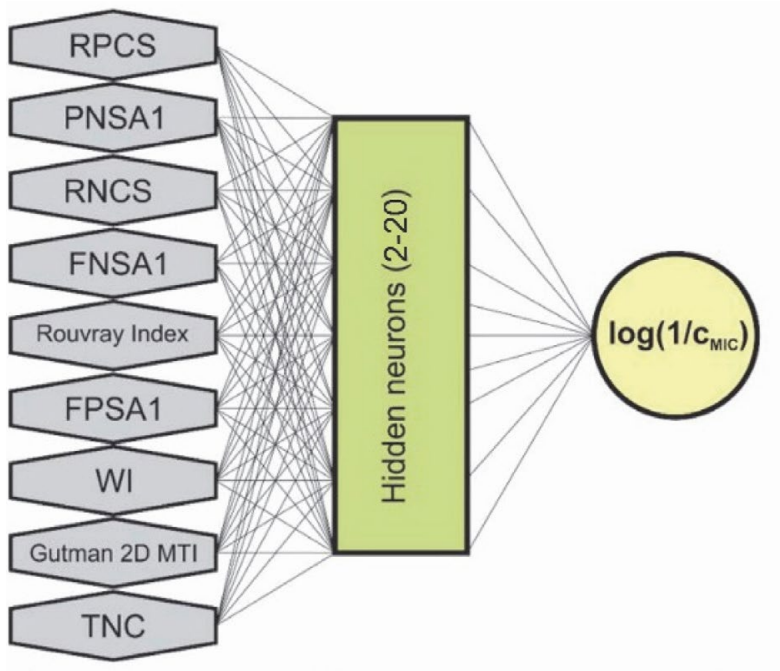

Input layer

Hidden layer

Output layer

Figure 2. The general architecture of the established QSAR-ANN models. cal parameters are presented in Table 2. The comparison of statistical quality of the obtained ANNs was done based on these parameters. Exponential (Exp) and tangent (Tanh) functions were used as MLP activation functions for hidden and output neurons. The total number of 150 ANNs was obtained, but only three ANNs were chosen as the best ones. During the training of the networks, the number of neurons in the hidden layer varied in the range of 2-20. The architecture of the obtained ANNs is presented in Figure 2 .

Based on the data given in Table 2 it can be seen that the statistical quality of selected ANNs is very similar. The comparison of the ANNs quality was estimated by comparing their $R$ and $R M S E$ values (Figure 3). The comparisons of RMSE and $R$ indicate that the network MLP 9-14-1 make the best concurrence of the data (the highest $R$ ) with the lowest RMSE values (Figure 3).

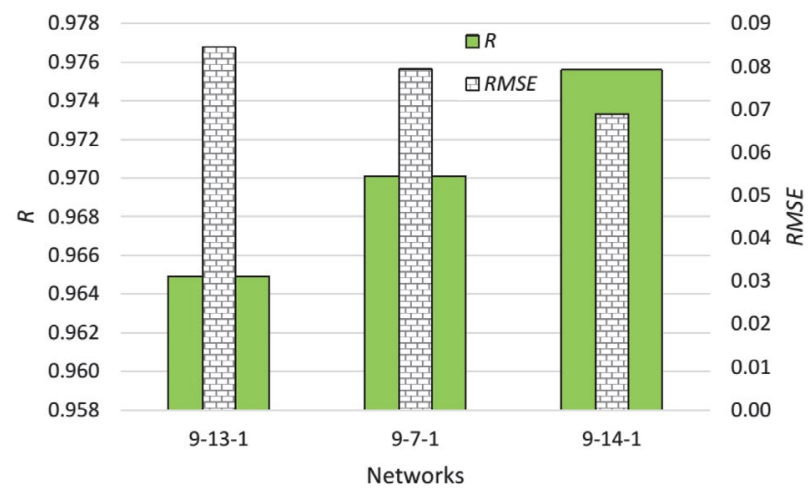

Figure 3. Comparisons of $\mathrm{R}$ and RMSE values of the established networks.

The prediction ability of the established networks is tested by the graphical comparison of the predicted and experimental $\log \left(1 / c_{\text {MIC }}\right)$ values (Figure 4$)$. The outstanding concurrence between the predicted and experimental values and small scattering of the points around linear relationship indicate high quality of the obtained models. Also, the slope of this linear relationship is very close to 1 and the intercept is very close to zero. This is another proof of the outstanding predictive ability of the ANNs. The residuals versus predicted $\log \left(1 / c_{\text {MIC }}\right)$ values plots for the established networks are presented in Figure 5. The presented ANN models fit the data well since the residuals behave randomly, which is obvious from the presented plots. The amplitude of the residuals is in acceptable range. The application of the external test set confirmed the quality of the established networks.

Other confirmation of reliability of the obtained networks is individual percentage deviations (IPD\%) for experimental-predicted values pairs. Figure 6 shows that all three ANNs have almost all IPD\% values lower than 2.0\% which indicates acceptable differences between predicted and experimental $\log \left(1 / c_{\text {MIC }}\right)$ values. 
MLP 9-7-1

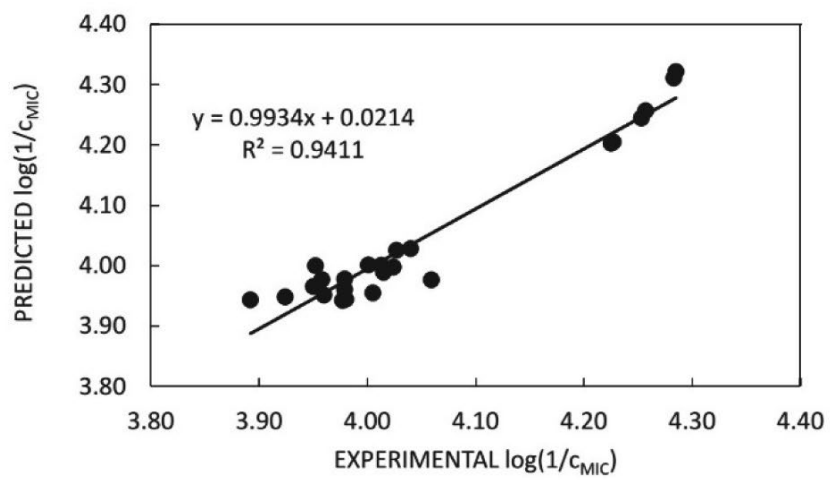

MLP 9-13-1

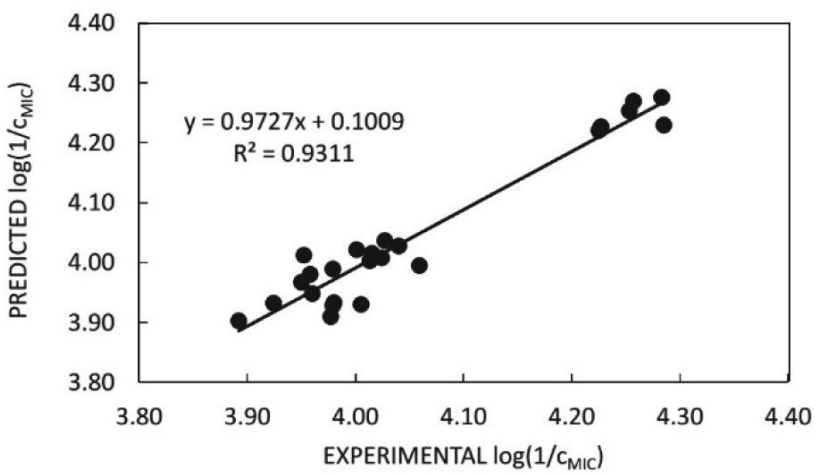

MLP 9-14-1

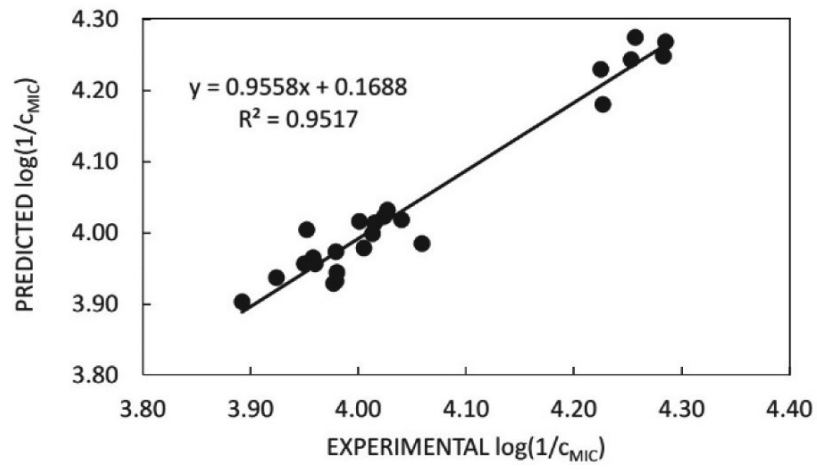

Figure 4. Correlations between the experimental and predicted antifungal activity of the analysed compounds.

MLP 9-7-1

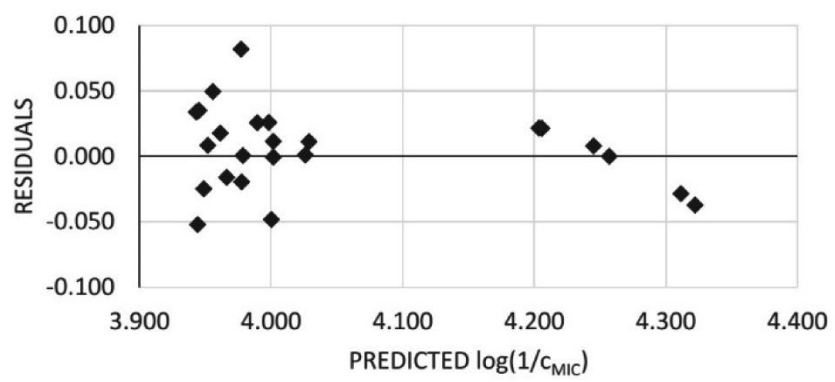

MLP 9-13-1

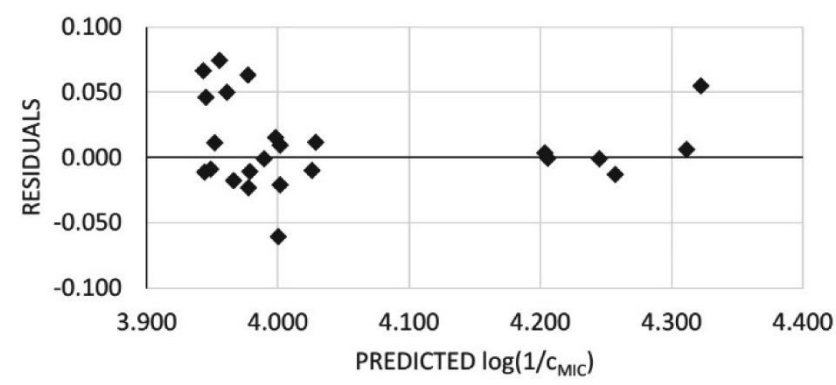

MLP 9-14-1

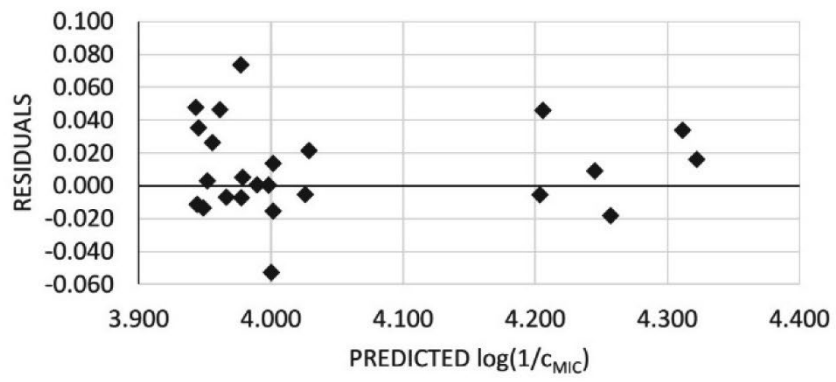

Figure 5. Predicted vs. residual values plots.

\section{3. Global Sensitivity Analysis}

As the result of global sensitivity analysis, the GSA coefficients were calculated by the applied software for ev- ery input variable. A GSA coefficient is presented in the following form:

$$
\mathrm{GSA}=E R R_{o} / E R R_{p}
$$

Kovačević et al.: Electrostatic and Topological Features as Predictors ... 


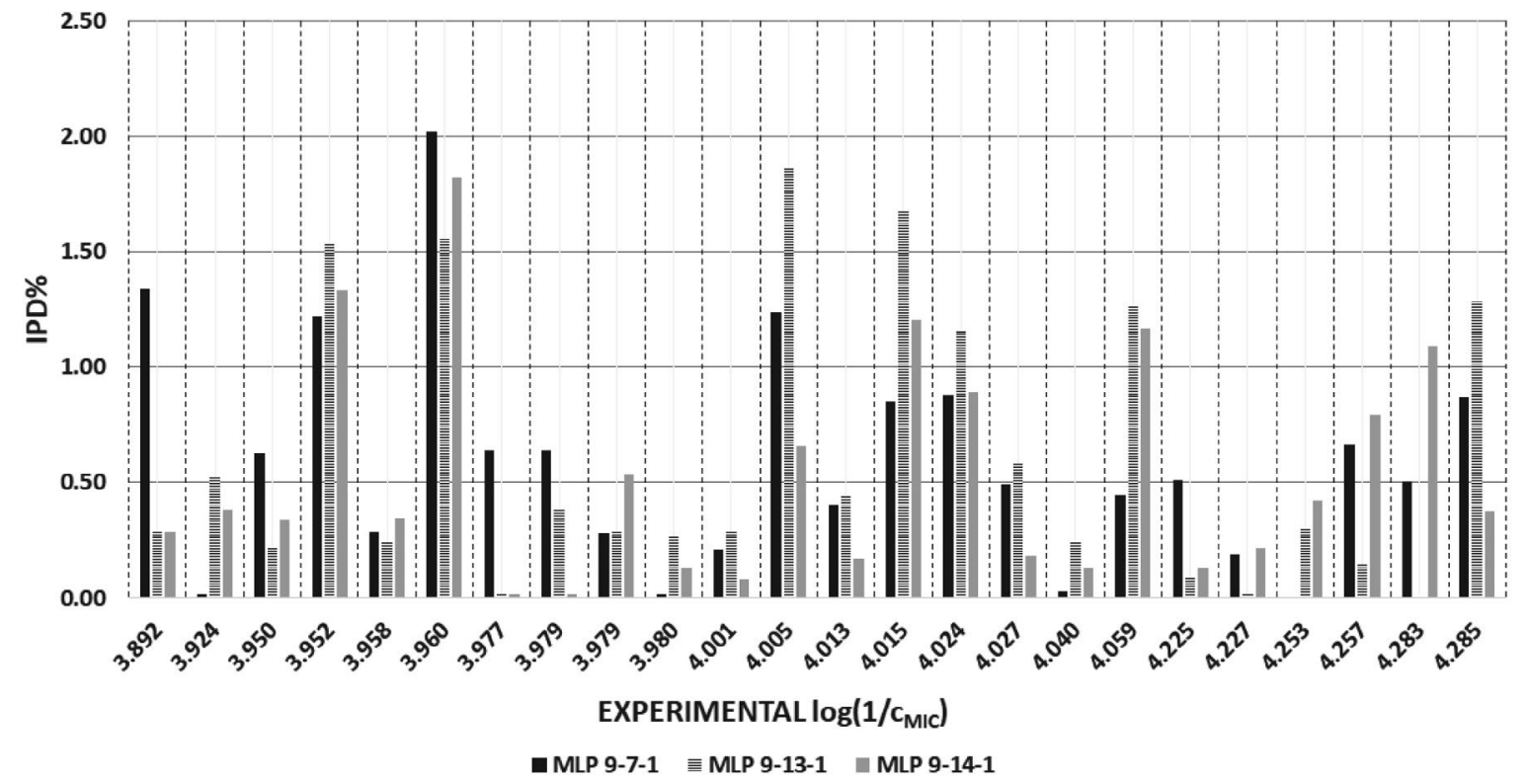

Figure 6. Individual percentage deviations (IPD\%) of predicted values compared with the experimental values.

where $E R R_{o}$ is the network error when the observed input variable is omitted and $E R R_{p}$ is the network error when the observed input variable is included in the model. The GSA coefficients for MLP 9-7-1, MLP 9-13-1 and MLP 9-14-1 networks are given in Figure 7. As it is shown in the pie charts, each input variable is described by GSA coefficient higher than 1 . This indicates a significance of each input variable, particularly the significance of RPCS, FPSA1 and PNSA1 descriptors (the highest average GSA coefficients).

In comparison with the results of QSAR analysis of oxazolo[4,5-b]pyridines and benzoxazoles previously published in literature, ${ }^{13,14}$ the results described in the present paper are based on non-linear prediction of their antifungal activity based on topological and electrostatic descriptors, while in the previous studies ${ }^{13}$ the linear modeling (PCR and PLS) of the antifungal activity have been carried out on the basis of some physicochemical and lipophilicity descriptors, as well as non-linear prediction (ANN) of antifungal activity based on some ADME descriptors. ${ }^{14}$ The presented results emphasized the influence of electrostatic and topological molecular features on the antifungal activity based on the established non-linear models. These models can be considered slightly statistically better than the models presented in literature. ${ }^{13,14}$

\section{4. Sum of Ranking Differences Analysis of Oxazolo[4,5-b]pyridines and Benzoxazoles}

SRD analysis was carried out on the basis of average row values as the reference value of the variables included in the ANN models (consensus ranking). The results of the SRD analysis (Figure 8) indicate the separation of the compounds into three main groups and detection of one outlier.
The first group (the compounds $2,10,13,17,19,20,21,22$ and 23) is characterized by the ranking number 0 , which means that these compounds have the same ranking as the reference one. The second group (the compounds $\mathbf{1}, \mathbf{3}, \mathbf{4}, \mathbf{5}$, $7,8,11,12,14,15$ and 16) has the ranking number 2 and third group (the compounds 6, 9 and 24) the ranking number 4 . The second and third group are considered to be very close to the reference ranking and contain most of the benzoxazole derivatives. However, the compound 18, with the ranking number 6 , is separated from the other compounds, but still can be considered relatively close to the reference ranking in the variable space (since it fits very well in the established QSAR models, it is not considered to be an outlier in the QSAR models). This compound has most of the molecular descriptors that are significantly different from the molecular descriptors of other compounds. Generally, oxazolo[4,5- $b]$ pyridines are placed in the first group, indicating their distinctiveness regarding RPCS, PNSA1, RNCS, FNSA1, Rouvray index, FPSA1, WI, Gutman 2D MTI and TNC molecular features. The compounds 9 and 24 from the third group are specific due to the presence of $-\mathrm{NO}_{2}$ functional group in their structures. The presented results of SRD analysis of oxazolo[4,5- $b$ ]pyridines and benzoxazoles revealed particular similarities/dissimilarities among the analyzed derivatives. This fact could be particularly interesting for further 3D-QSAR and 4D-QSAR modeling and molecular docking studies of antifungal activity of oxazolo[4,5- $b]$ pyridines and benzoxazoles toward Candida albicans.

\section{Conclusions}

The conducted variable selection procedure and artificial neural network modeling resulted in three reliable 

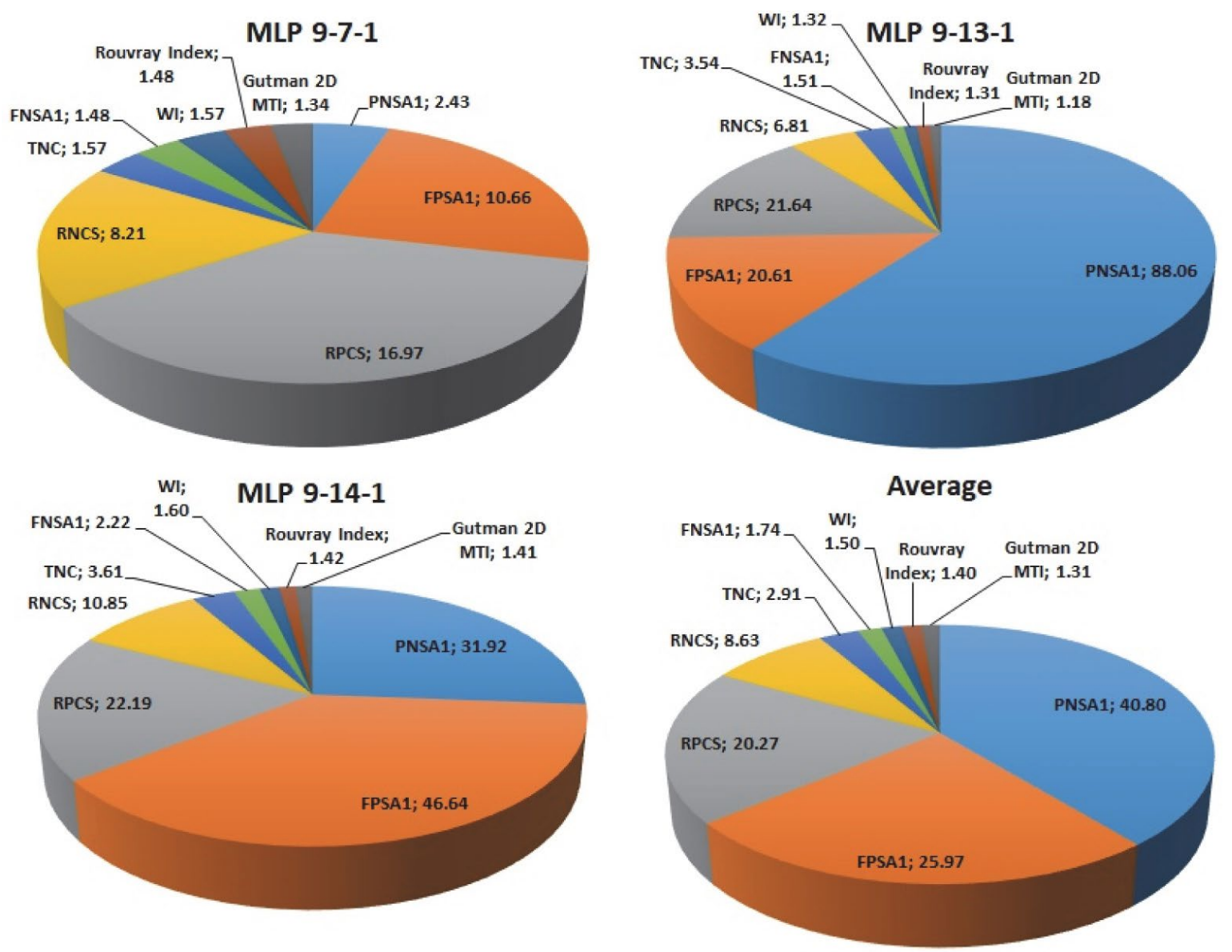

Figure 7. The GSA coefficients of the established ANNs and their average values.

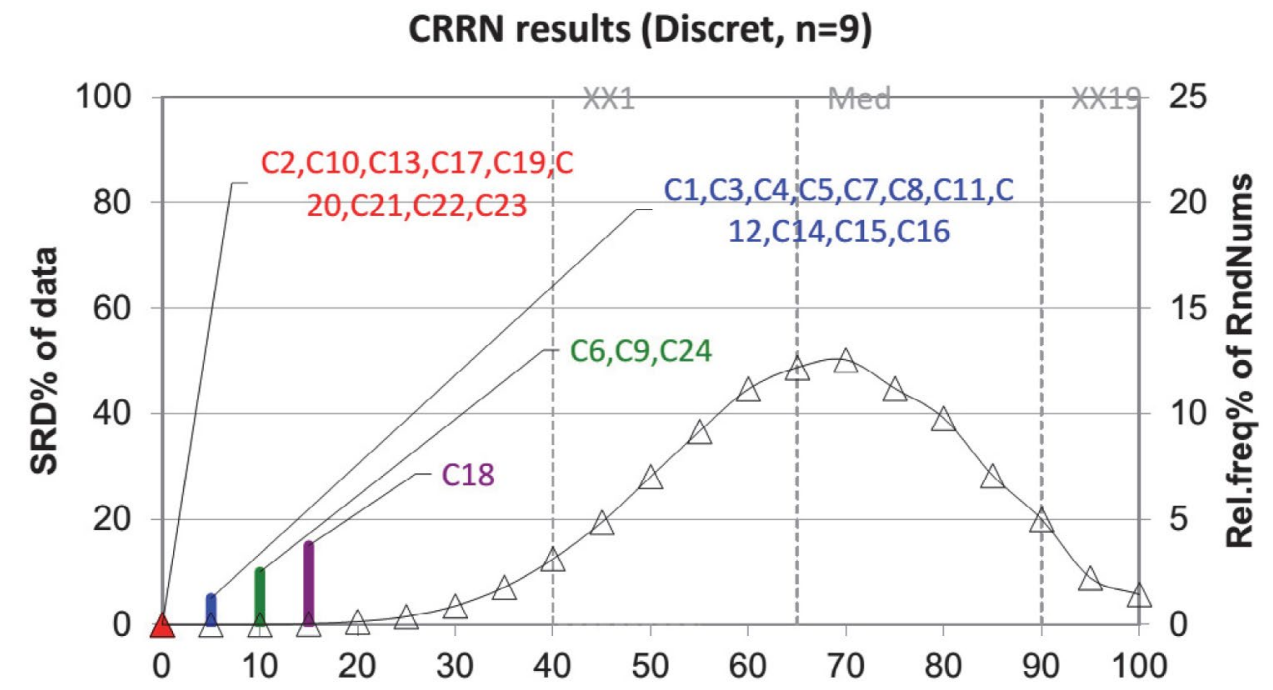

Figure 8. The result of SRD-CRRN analysis of oxazolo[4,5-b]pyridines and benzoxazoles. The statistical properties of theoretical distribution function are: first icosaile $(5 \%), \mathrm{XX1}=16$; first quartile, $\mathrm{Q} 1=22$; median, Med = 26; last quartile, Q3 = 32; last icosaile $(95 \%)$, XX19=36.

neural networks which can be used in prediction of antifungal potential of structurally similar oxazolo[4,5-b]pyridines and benzoxazoles. The prediction ability of the obtained networks has been confirmed by adequate statistical measures, by comparisons of the experimental and predicted data including the residuals analysis. Applying stepwise selection procedure, the most important electrostatic and topological descriptors were determined: RPCS, 
PNSA1, RNCS, FNSA1, Rouvray index, FPSA1, WI, Gutman 2D MTI and TNC. These descriptors can be used as predictor variables in assessment of minimum inhibitory concentrations of novel oxazolo[4,5- $b]$ pyridine and benzoxazole derivatives prior to their synthesis, and in that way, facilitate synthesis of more effective antifungal agents. The SRD-CRRN analysis, which was based on the molecular descriptors included in the ANN models and average row values as a reference ranking, detected certain structural similarities in the applied variable space.

\section{Acknowledgement}

The research presented in this paper is financially supported by the Project No. 172012 of the Ministry of Education, Science and Technological Development of the Republic of Serbia.

\section{Abbreviations}

ADME - Absorption, Distribution, Metabolism and Excretion

ANN - Artificial Neural Networks

BFGS - Broyden-Fletcher-Goldfarb-Shanno algorithm

CRRN - Comparison of Ranks with Random Numbers

GSA - Global Sensitivity Analysis

HCA - Hierarchical Cluster Analysis

LR - Linear Regression

MIC - Minimum Inhibitory Concentration

MLP - Multi Layer Perceptron

PCA - Principal Component Analysis

PCR - Principal Component Regression

PLS - Partial Least Squares

PR - Polynomial Regression

QSAR - Quantitative Structure-Activity Relationship

QSPR - Quantitative Structure-Property Relationship

RMSE - Root Mean Square Error

SRD - Sum of Ranking Differences

\section{References}

1. G. Thomas (Ed.), Fundamentals of Medicinal Chemistry, 1st edn, John Wiley and Sons, New York, 2003, pp 71-93.

2. S. O. Podunavac-Kuzmanović, D. D. Cvetković, D. J. Barna, Int. J. Mol. Sci. 2009, 10, 1670-1682.

DOI:10.3390/ijms1004167

3. B. Hemmateenejad, J. Chemometr. 2004, 18, 475-485.

DOI:10.1002/cem.891

4. O. Farkas, J. Jakus, K. Heberger, Molecules 2004, 9, 1079-1088. DOI:10.3390/91201079

5. A. Puratchikody, G. Nagalakshmi, M. Doble, Chem. Pharm. Bull. 2008, 56, 273-281. DOI:10.1248/cpb.56.273

6. S. O. Podunavac-Kuzmanović, D. D. Cvetković, L. R. Jevrić,
N. J. Uzelac, Acta Chim. Slov. 2013, 60, 26-33.

7. S. Z. Kovačević, S. O. Podunavac-Kuzmanović, L. R. Jevrić, E. A. Djurendić, J. J. Ajduković, Eur. J. Pharm. Sci. 2014, 62, 258-266. DOI:10.1016/j.ejps.2014.05.031

8. I. N. Weaver, D. F. Weaver, J. Math. Chem. 2013, 51, 811-816. DOI:10.1007/s10910-013-0143-x

9. R. Todeschini, V. Consoni (Eds.), Handbook of molecular descriptors, Wiley-VCH, Dusseldorf, Germany, 2000, pp 50-58. DOI:10.1002/9783527613106

10. S. G. Whaley, E. L. Berkow, J. M. Rybak, A. T. Nishimoto, K. S. Barker, P. D. Rogers, Front. Microbiol. 2017, 7, 2173, 1-12.

11. S. O. Podunavac-Kuzmanović, S. D. Velimirović, APTEFF 2010, 41, 177-185. DOI:10.2298/APT1041177P

12. S. O. Podunavac-Kuzmanović, L. R. Jevrić, S. Z. Kovačević, N. D. Kalajdžija, APTEFF 2012, 43, 273-282. DOI:10.2298/APT1243273P

13. S. Z. Kovačević, S. O. Podunavac-Kuzmanović, L. R. Jevrić, Acta Chim. Slov. 2013, 60, 756-762.

14. S. Z. Kovačević, S. O. Podunavac Kuzmanović, L. R. Jevrić, N. D. Kalajdžija, APTEFF 2013, 44, 249-258. DOI:10.2298/APT1344249K

15. O. Ursu, A. Costescu, M. V. Diudea, B. Parv, Croat. Chem. Acta 2006, 79, 483-488.

16. PreADMET software, URL: http://preadmet.bmdrc.org/ (Assessed on April 4, 2017)

17. Hintze J, NCSS and GESS, NCSS, LLC, Kaysville, Utah, http:// www.ncss.com/

18. S. B. Gadzuric, S. O. Podunavac Kuzmanovic, A. I. Jokic, M. B. Vranes, N. Ajdukovic, S. Z. Kovacevic, Aust. J. Forensic. Sci. 2014, 46, 166-179. DOI:10.1080/00450618.2013.825812

19. StatSoft Inc., 2300 East 14th Street, Tulsa, Oklahoma, USA: http://www.statsoft.com/

20. T. Jayalakshmi, A. Santhakumaran, IJCTE 2011, 3, 89-93. DOI:10.7763/IJCTE.2011.V3.288

21. A. I. Jokić, J. A. Grahovac, J. M. Dodić, S. N. Dodić, S. D. Popov, Z. Z. Zavargo, D. G. Vučurović, Hem Ind 2012, 66, 211-221. DOI:10.2298/HEMIND110805085J

22. R. Therón, J. F. De Paz, Visual sensitivity analysis for artificial neural networks: Intelligent Data Engineering and Auromated Learning - IDEAL, $7^{\text {th }}$ International Conference, Conference Proceeding, Burgos, Spain, 2006. DOI:10.1007/11875581_23

23. M. H. Shojaeefard, M. Akbari, M. Tahani, F. Farhani, $A d v$. Mater. Sci. Eng. 2013, 2013, 1-7.

24. K. Héberger, K. Kollár-Hunek K, J. Chemometr. 2011, 25, 151-158. DOI:10.1002/cem.1320

25. K. Kollár-Hunek, K. Héberger, Chemom. Intell. Lab. Syst. 2013, 127, 139-146. DOI:10.1016/j.chemolab.2013.06.007

26. S. Z. Kovačević, S. O. Podunavac-Kuzmanović, L. R. Jevrić, E. A. Djurendić, J. J. Ajduković, S. B. Gadžurić, M. B. Vraneš, J. Iran. Chem. Soc. 2016, 13, 499-507. DOI:10.1007/s13738-015-0759-9

Kovačević et al.: Electrostatic and Topological Features as Predictors ... 


\section{Povzetek}

Rezultati, predstavljeni v tej študiji, vključujejo napoved protiglivične aktivnosti 24 derivatov oksazola, ki temeljijo na njihovih topoloških in elektrostatičnih molekularnih deskriptorjih, ki izhajajo iz $2 \mathrm{D}$ molekularnih struktur. Metoda umetnega nevronskega omrežja (ANN) je bila uporabljena kot regresijsko orodje. Vhodni podatki za modeliranje ANN so bili izbrani s postopnim izbiranjem (SS). Modeliranje ANN je privedlo do treh mrež z izjemnimi statističnimi značilnostmi. Visoka predvidljivost vzpostavljenih omrežij je bila potrjena s primerjavami predvidenih in eksperimentalnih podatkov ter s preostalo analizo. Dobljeni rezultati kažejo na koristnost nastalih ANN pri natančni napovedi minimalnih inhibitornih koncentracij analiziranih spojin proti Candida albicans. V tej študiji je bila uporabljena metoda vsote razvrstitvenih razlik (SRD), da bi razkrili možno združevanje spojin v prostoru spremenljivk, uporabljenih pri modeliranju ANN. Dobljene rezultate lahko štejemo kot prispevek k razvoju novih protiglivičnih zdravil, ki strukturno temeljijo na oksazolnem jedru, še posebej v današnjih časih, ko primanjkuje visoko učinkovitih antimikotikov 